\title{
RECRUITMENT AND RETENTION OF COMMUNITY SECTOR LAWYERS: REGIONAL DIFFERENCES WITHIN NeW SOUTH WALES
}

\section{Michael Cain ANd SuZie Forell*}

\begin{abstract}
The Aboriginal Legal Service, Community Legal Centres, Legal Aid NSW and private solicitors undertaking legal aid work all have a role in meeting the legal needs of disadvantaged communities in rural, regional and remote $(R R R)$ parts of NSW. Yet there are reports that staff shortages are affecting the capacity of these services to perform this work - in some areas more than others. In order to gain a 'snapshot' of solicitor availability in RRR areas and to assess any regional differences in their availability to undertake community sector legal work in NSW, the Law and Justice Foundation of NSW has undertaken a census of all public legal assistance positions in NSW. The study examined whether the positions were filled or vacant, how they were filled, and the length of time that they were filled (or vacant). The research also drew upon data from the NSW Law Society and the three main public legal services in NSW to map solicitor availability across NSW against a range of indicators, including socio-economic disadvantage. In addition, interviews were conducted with solicitors working in (and who had left) 'hard to staff' areas with a view to better understanding differences in the recruitment and retention of solicitors across RRR areas of NSW. The major findings of the Foundation's full research report ${ }^{1}$ are discussed in this paper.
\end{abstract}

\footnotetext{
* Senior Researchers with the Law and Justice Foundation of NSW: <http://www. lawfoundation.net.au>.

${ }^{1}$ Suzie Forell, Michael Cain and Abigail Gray, 'Recruitment and Retention of Lawyers in Regional, Rural and Remote NSW' (Research Report, Law and Justice Foundation of NSW, September 2010) <http://www.lawfoundation.net.au/ljf/site/articleIDs/53FAC0137BED 4F38CA2577BA0024256B/\$file/Recruitment_and_retention_of_lawyers_in_RRR_NSW_we b.pdf $>$. This study was undertaken by the Foundation on behalf of the NSW Legal Assistance Forum RRR Working Group and was funded in large part by the Australian Government Attorney-General's Department Social Inclusion Division.
} 


\section{BACKGROUND}

There has been growing concern about the shortage of lawyers working in regional, rural and remote (RRR) areas throughout Australia. ${ }^{2}$ Public legal services for disadvantaged people in NSW have also reported difficulties in recruiting and retaining solicitors in RRR areas, ${ }^{3}$ as well as difficulties in attracting sufficient private solicitors to undertake legal aid work. ${ }^{4}$

Within the broader context of the social and economic decline experienced by rural Australia, the populations of many RRR areas have been decreasing for decades. $^{5}$

${ }^{2}$ See, eg, Law and Justice Foundation of NSW, Access to Justice Roundtable: Proceedings of a Workshop, July 2002 (Law and Justice Foundation of NSW, 2003) 39-40<http://www. lawfoundation.net.au/ljf/site/articleIDs/52183CCAB00DB476CA2572730018E0C8/\$file/AJR _book.pdf>; Senate Legal and Constitutional References Committee, Parliament of Australia, $\bar{L}$ egal Aid and Access to Justice (2004) ch $6<$ http://www.aph.gov.au/senate/committee/ legcon_ctte/legalaidjustice/report.pdf $>$; National Pro Bono Resource Centre, 'Regional, Rural and Remote Pro Bono: Models and Opportunities' (Information Paper, National Pro Bono Resource Centre, May 2006) 5, <http://www.nationalprobono.org.au/publications/documents/ RRRPaper.pdf>; TNS Social Research, 'Study of the Participation of Private Legal Practitioners in the Provision of Legal Aid Services in Australia' (Research study paper prepared for the Attorney-General's Department, TNS Social Research, December 2006) vii $<$ http://www.ema.gov.au/www/agd/rwpattach.nsf/VAP/\%28CFD7369FCAE9B8F32F341DB E097801FF\%29 88newLegal+Aid+research+TNS+report+FINAL.pdf/\$file/88newLegal+Ai d+research+TNS+report+FINAL.pdf >; Legal Aid NSW, Annual Report 2007-2008 (Legal Aid NSW, 2008); Law Council of Australia and Law Institute of Victoria 'Report into the Rural, Regional and Remote Areas Lawyers Survey' (Research Report, Law Council of Australia and Law Institute of Victoria, July 2009) <http://www.lawcouncil. asn.au/shadomx/apps/fms/fmsdownload. cfm?file_uuid=58075666-1E4F-17FA-D22C-92C 2CC13DA7C\&siteName $=$ lca $>$.

${ }^{3}$ Trish Mundy, Recruitment and Retention of Lawyers in Rural, Regional and Remote NSW: A Literature Review (Research paper, Northern Rivers Community Legal Centre, 2008).

${ }^{4}$ Legal Aid NSW, Annual Report 2007-2008 (Legal Aid NSW, 2008) $30<$ http://www. legalaid.nsw.gov.au/data/portal/00000005/public/14853001228351482318.pdf>.

${ }^{5}$ See, eg, Human Rights and Equal Opportunities Commission, "'Emerging Themes": National Inquiry into Rural \& Remote Education' (Inquiry Summary, Human Rights and Equal Opportunities Commission, 2000); Chris Cocklin and Jacqui Dibden, 'Regional Dimensions in National Development: A Perspective from Rural Australia' (Research Report, Bureau of Infrastructure, Transport and Regional Economics, Feburary 2004) $<$ http://www.btre.gov.au/ publications/87/Files/c_cocklin.pdf>; Phil Roberts, 'Staffing an Empty Schoolhouse: Attracting and Retaining Teachers in Rural, Remote and Isolated Communities' (Research Paper, New South Wales Teachers Federation, 2004) <http://www.acsso.org.au/ roberts070501.pdf $>$. 
Mirroring this general decline, many country areas have lost doctors, dentists, teachers, lawyers and other professionals. ${ }^{6}$

To date, a limitation of much of the previous research into the availability of lawyers in RRR areas has been the tendency to focus on differences between country and city areas, with country areas treated as a homogeneous whole. ${ }^{7}$ There has been at least some evidence, however, to suggest that recruitment and retention problems are more nuanced and vary from region to region, and that there has not been a net loss of solicitors in RRR areas in NSW. ${ }^{8}$ The Foundation's research was undertaken to obtain more comprehensive, location-specific information on the recruitment and retention of lawyers in RRR NSW.

Legal services to disadvantaged people in NSW are met through a combination of public (Legal Aid, Aboriginal Legal Services and Community Legal Centres) and private legal services (through grants of legal aid). While each of these services fundamentally operates independently of the others, they cannot be considered in isolation, particularly in regional areas which have few resident lawyers of any sort. For this reason, this study commenced with an analysis of the distribution of all public and private solicitors in NSW. The next step was to examine every solicitor position statewide within Legal Aid NSW, NSW Community Legal Centres (CLCs) and the Aboriginal Legal

\footnotetext{
${ }^{6}$ See, eg, R Miles et al, 'The Attraction and Retention of Professionals to Regional Areas' (Research Report, Central Queensland University, c 2004) <http://www.bowenbasin.cqu.edu. au/pdfs/dotars_colloq.pdf $>$; Phil Roberts, 'Staffing an Empty Schoolhouse: Attracting and Retaining Teachers in Rural, Remote and Isolated Communities' (Research Paper, New South Wales Teachers Federation, 2004) <http://www.acsso.org.au/roberts070501.pdf >; Legislative Council Standing Committee on State Development, Parliament of New South Wales, Inquiry into Skills Shortages in Rural and Regional New South Wales (2006) <http://www.parliament. nsw.gov.au/Prod/parlment/committee.nsf/0/f38fab9bb76cd71aca25716b0005c993/\$FILE/Fin al\%20Skills\%20Report\%2011\%20May\%202006.pdf>.

${ }^{7}$ See, eg, TNS Social Research, 'Study of the Participation of Private Legal Practitioners in the Provision of Legal Aid Services in Australia' (Research study paper prepared for the Attorney-General's Department, TNS Social Research, December 2006) <http://www.ema. gov.au/www/agd/rwpattach.nsf/VAP/\%28CFD7369FCAE9B8F32F341DBE097801FF\%29 8 8newLegal+Aid+research+TNS+report+FINAL.pdf/\$file/88newLegal+Aid+research+TNS+r eport+FINAL.pdf >; Law Council of Australia, 'New South Wales Rural, Regional and Remote Area Lawyers Survey' (Survey Data Report (State Snapshot for NSW), Law Council of Australia, July 2009) <http://www.lawcouncil.asn.au/shadomx/apps/fms/fmsdownload. cfm?file_uuid=58024F1B-1E4F-17FA-D295-349CEC7C2460\&siteName=lca $>$.

${ }^{8}$ Suzie Forell, Michael Cain and Abigail Gray, 'Recruitment and Retention of Lawyers in Regional, Rural and Remote NSW' (Research Report, Law and Justice Foundation of NSW, September 2010) vii-ix <http://www.lawfoundation.net.au/ljf/site/articleIDs/ 53FAC0137BED4F38CA2577BA0024256B/\$file/Recruitment_and_retention_of_lawyers_in _RRR_NSW_web.pdf $>$.
} 
Service NSW/ACT (ALS). These services are the main not-for-profit services providing legal assistance to disadvantaged people in metropolitan and rural NSW.

The research also examined private solicitors delivering legal services to disadvantaged people in regional areas through assigned legal aid case work. This is in recognition of the fact that 56 per cent of all legally aided case work (ie grants of legal aid) in NSW is assigned to private lawyers. ${ }^{9}$

\section{The Study}

The study involved both quantitative and qualitative research methods. To provide the broad contextual picture, a snapshot was taken from the NSW Law Society's data on all solicitors holding a NSW practising certificate on 30 June 2009. To explore recruitment and retention issues in public legal assistance agencies, a separate census was taken on 30 June 2009 of all filled and vacant solicitor positions in the ALS (NSW positions), NSW CLCs and Legal Aid NSW.

Recognising the role of the private sector in providing legal assistance to disadvantaged people, the study examined all legal aid grants assigned to private solicitors in 2008/09 and all registered private practitioner legal aid panel members during that time.

The study also included a survey of selected solicitors who either were working in or who had left public legal assistance service jobs in RRR areas (including nominally identified 'hard to recruit' areas). Managers responsible for staffing RRR legal services were also included among those surveyed.

\footnotetext{
${ }^{9}$ Legal Aid NSW, Annual Report 2008-2009 (Legal Aid NSW, 2009) <http://www.legalaid. nsw.gov.au/asp/index.asp?pgid=784>.
} 


\section{RESULTS}

\section{A The Distribution of Public and Private Solicitors in NSW}

On the snapshot date of 30 June 2009, there were 19381 private and public solicitors practising in NSW, or 296 solicitors for every 100000 persons in NSW. Overall, the ratio of residents to locally based solicitors increased with the remoteness of the area. In NSW, the Inner Regional areas had a ratio of one resident solicitor for every 1000 residents. This increased to one resident solicitor for every 2000 residents in Outer Regional NSW. In the Remote and Very Remote areas of NSW, there was one resident solicitor for every 3000 residents. ${ }^{10}$

It should further be noted that offices of the main public legal services in NSW are not evenly spread across NSW. In particular, there are no Legal Aid NSW offices located in Outer Regional, Remote or Very Remote areas of NSW (see figures 1a, 2a and 3a in full report). ${ }^{11}$ Compared to Legal Aid NSW and CLCs, there are more ALS offices placed in the more remote parts of the state. ALS offices are located in Outer Regional as well as Remote and Very Remote areas and, therefore, are in close proximity to the more disadvantaged communities in country NSW.

The distribution of all solicitors (public and private) by Region (ie Statistical Division) is mapped in Figure 1. Only 6.6 per cent of solicitors were practising law in RRR areas of NSW. Notably, within the largest (but least populated) geographic region of NSW - the Far West - there were only ten practising solicitors registered with the NSW Law Society. The Far West region also had the lowest rate (45.4) of solicitors per 100000 residents, which translates to one solicitor for every 2000 persons living in this region.

\footnotetext{
${ }^{10}$ It is generally the case that the more remote and inaccessible the area in NSW, the higher the level of socio-economic disadvantage and the higher the proportion of Indigenous persons. These characteristics are commonly associated with higher levels of legal need: Christine Coumarelos, Zhigang Wei and Albert Z Zhou, 'Justice Made to Measure: NSW Legal Needs Survey in Disadvantaged Areas' (Research Report, Law and Justice Foundation of NSW, March 2006) <http://www.lawfoundation.net.au/report/survey2006>.

${ }^{11}$ Rather, Legal Aid NSW Offices outside of the metropolitan areas are based in regional centres in Inner Regional NSW. People in smaller rural towns and more remote areas may be supported by these offices, or by private lawyers undertaking legal aid work.
} 
Figure 1: Solicitors with NSW practising certificate - location of principal place of practice and rate of solicitors per 100000 residents by NSW Region (SD), 30 June 2009

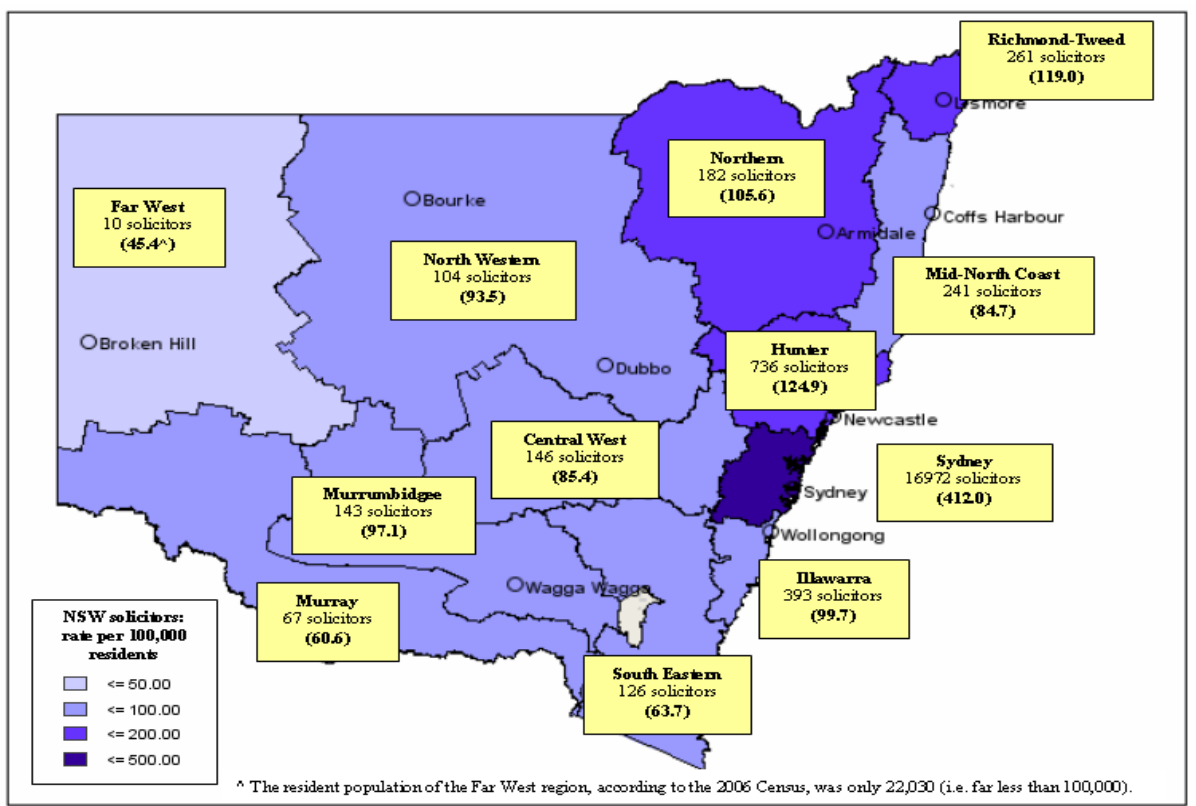

\begin{tabular}{lllllll}
\hline & 100 & 200 & 300 & 400 & 500 & $\mathrm{~km}$
\end{tabular}

Source: NSW Law Society database (30 June 2009). Figure 7 in full report.

Contributing to the uneven spread of solicitors across NSW, it was found that there were 19 Local Government Areas (LGAs) in NSW that did not have a single solicitor - private or public - based in the area on 30 June 2009 (Figure 8 in full report). All of these 19 LGAs were characterised by resident populations of less than 7000 persons, relatively high levels of socioeconomic disadvantage and, for 17 of these 19 LGAs, their populations were in actual or relative decline.

These findings would seem to suggest that in some areas, particularly the more remote and less populated parts of country NSW, there may not be enough legal work - private or public — to sustain a full-time resident solicitor.

Without necessarily discounting the possibility of outreach services or duty lawyer services operating in these areas, it is possible that residents of these 19 LGAs travelled elsewhere, perhaps to their closest regional centre, to obtain legal assistance. However, it is also possible that in these areas (as in 
other disadvantaged areas) some people with a legal problem may not have sought help at all. ${ }^{12}$

There are important differences between the number and distribution of private solicitors and public legal assistance solicitor positions in NSW. To begin with, on the census date, only four per cent of solicitors practising in NSW worked in Legal Aid, CLC or ALS solicitor positions. Secondly, it appears that the more remote (and disadvantaged) the area, the higher the ratio of public or community legal sector solicitors compared to private solicitors. For example, while the Far West region had the lowest ratio of resident solicitors to population in NSW (45 solicitors versus a NSW average of 296 solicitors for every 100000 persons), it had the highest ratio of resident public legal assistance solicitors to population in NSW (25 public legal assistance solicitors compared with a NSW average of approximately 10 public legal assistance solicitors for every 100000 persons).

Some regions have fewer public legal assistance services (and solicitors) than others. South Eastern had only an ALS office (no CLC or Legal Aid NSW), Murray had only a CLC (no ALS or Legal Aid NSW). There were no CLCs in the Mid-North Coast, Central West, South Eastern or Murrumbidgee regions. The presence of a CLC, a Family Violence Prevention Legal Service and the ALS in Broken Hill contributed to the higher per capita rate of public legal assistance solicitors in the Far West, even though there was no Legal Aid NSW office in this region.

\section{B Regional Differences in Solicitor Availability by Area of Law}

To appreciate the potential impact of recruitment and retention issues in any one area, the availability of public legal assistance solicitors and solicitor positions also needs to be considered in the context of three additional factors: the mix of public to private solicitors performing public legal assistance work in each area; the types of law practised by each solicitor; and any other legal services provided to residents in each area. Two examples highlight these points.

With a reasonably sized population of 198000 people, South Eastern region appeared to have the lowest number of public legal assistance positions based

\footnotetext{
${ }^{12}$ Christine Coumarelos, Zhigang Wei and Albert Z Zhou, 'Justice Made to Measure: NSW Legal Needs Survey in Disadvantaged Areas' (Research Report, Law and Justice Foundation of NSW, March 2006) <http://www.lawfoundation.net.au/report/survey2006>.
} 
in the region. It had no public legal assistance solicitor practising civil law (no CLC), only one part-time resident Legal Aid solicitor providing family law services, and three ALS solicitors providing criminal law support, and then only to Indigenous clients. However, complementing the work of these public legal assistance solicitors were local private lawyers who were assigned grants of legal aid. In 2008/09, South Eastern region had 37 private solicitors on the Legal Aid NSW criminal law panel, 31 on the family law panel, 16 private solicitors on the care and protection panel and nine on the civil law panel (a solicitor may be a member of more than one panel). In terms of actual grant activity in 2008/09, there were 1329 grants of legal aid assigned to private solicitors based in the South Eastern region - 63 per cent for criminal matters, 21 per cent for family matters and 16 per cent for care and protection matters. Only six grants were assigned for civil matters.

Similarly, the Central West region, with a general population of 171000 , had no public legal assistance solicitor practising civil law (no CLC), only one public legal assistance solicitor providing family law services, and seven public legal assistance solicitors practising criminal law. However, private solicitors based in the Central West region handled 1117 grants of legal aid in 2008/09 - 38 per cent for criminal matters, 42 per cent for family matters and 18 per cent for care and protection matters. Only 20 grants were assigned for civil matters.

The availability of private practitioners willing to undertake public legal assistance work is a key consideration to the delivery of legal services in RRR areas, given that private solicitors are more evenly distributed across the state and undertake a considerable proportion of legal aid work.

\section{Major Regional Differences in Public Legal Assistance Solicitor Availability, Recruitment and Retention}

Data from the major public legal assistance services on filled and vacant solicitor positions indicates considerable regional variation in recruitment and retention issues, both in terms of actual vacancies and in terms of the numbers of positions filled by a non-incumbent, such as a locum or a junior solicitor acting in the position (Table 1). 
Table 1: Distribution of vacant and otherwise unoccupied public legal assistance solicitor positions by NSW region (Statistical Division), 30 June 2009

\begin{tabular}{|c|c|c|c|c|c|c|c|c|}
\hline \multirow[b]{2}{*}{ Region (SD) } & \multicolumn{2}{|c|}{$\begin{array}{c}\text { Filled by } \\
\text { incumbent }\end{array}$} & \multicolumn{2}{|c|}{ Vacant } & \multicolumn{2}{|c|}{$\begin{array}{c}\text { Filled by } \\
\text { Non-incumbent }\end{array}$} & \multicolumn{2}{|c|}{$\begin{array}{c}\text { All solicitor } \\
\text { positions }\end{array}$} \\
\hline & $\mathbf{N}$ & $\%$ & $\overline{\mathbf{N}}$ & $\%$ & $\bar{N}$ & $\%$ & $\overline{\mathbf{N}}$ & $\%$ \\
\hline Sydney & 289 & 56.1 & 33 & 6.4 & 193 & 37.5 & $\overline{515}$ & 100.0 \\
\hline Hunter & 24 & 80.0 & 1 & 3.3 & 5 & 16.7 & 30 & 100.0 \\
\hline Illawarra & 26 & 74.3 & 2 & 5.7 & 7 & 20.0 & 35 & 100.0 \\
\hline $\begin{array}{l}\text { Richmond- } \\
\text { Tweed }\end{array}$ & 15 & 65.2 & 3 & 13.0 & 5 & 21.7 & 23 & 100.0 \\
\hline Mid-North Coast & 11 & 64.7 & 3 & 17.6 & 3 & 17.6 & 17 & 100.0 \\
\hline Northern & 14 & 93.1 & 1 & 6.7 & 0 & 0.0 & 15 & 100.0 \\
\hline North Western & 17 & 70.8 & 3 & 12.5 & 4 & 16.7 & 24 & 100.0 \\
\hline Central West & 6 & 75.0 & 0 & 0.0 & 2 & 25.0 & 8 & 100.0 \\
\hline South Eastern & 3 & $\begin{array}{r}100 . \\
0\end{array}$ & 0 & 0.0 & 0 & 0.0 & 3 & 100.0 \\
\hline Murrumbidgee & 13 & 86.7 & 2 & 13.3 & 0 & 0.0 & 15 & 100.0 \\
\hline Murray & 5 & 83.3 & 0 & 0.0 & 1 & 16.7 & 6 & 100.0 \\
\hline Far West & 2 & 33.3 & 2 & 33.3 & 2 & 33.3 & 6 & 100.0 \\
\hline NSW & 425 & 61.0 & 50 & 7.2 & 222 & 31.9 & 697 & 100.0 \\
\hline
\end{tabular}

Note: Row percentages add up to 100 per cent. Highlighted cells indicate that the region had an above average percentage of solicitor positions in that particular category.

Source: LJF census of NSW public legal assistance solicitor positions (30 June 2009): Table 18 in full report.

An overall vacancy rate of seven per cent for NSW does not appear alarming. However, the Far West, Mid-North Coast, Murrumbidgee, Richmond-Tweed and North Western regions had vacancy rates which were higher than the state average. The Far West had the highest vacancy rate, with one-third of its six public legal assistance solicitor positions vacant at the time the census was 
taken. In addition, a further two public legal assistance solicitor positions in the Far West were occupied by someone other than the incumbent.

While vacancies and non-incumbent filled positions are valid indicators of recruitment and retention difficulties, other measures, including the short times that positions remained filled or the long periods that vacant positions remained unfilled, give a more complete picture of the recruitment and retention difficulties experienced in different parts of NSW.

Furthermore, recruitment and retention issues must also be considered in the context of whether public legal assistance solicitor positions existed in a region in the first place. This is crucial given that there are no resident Legal Aid NSW solicitor positions based in areas that are more remote than Inner Regional NSW, and there are no CLCs situated in the Mid-North Coast, South Eastern and Murrumbidgee regions.

Considering all these indicators together, the parts of NSW which were identified as having the most difficulties in terms of the availability, recruitment and retention of solicitors for public legal assistance services were the Far West, Murrumbidgee and North Western regions. These three regions are described in terms of their major recruitment, retention and broader solicitor availability issues.

\section{$1 \quad$ Far West}

- With a total of only 10 private and public solicitors, Far West had the lowest per capita rate of solicitors in NSW (one resident solicitor for every 2000 persons). Therefore, the loss of even a single solicitor from this area will have a major impact.

- Two of six public legal assistance solicitor positions in this region were vacant ( 33 per cent compared to the state average of 7 per cent) on the census date.

- Two of the four occupied public legal assistance solicitor positions were filled by a non-incumbent.

- All ALS and CLC positions had been filled for relatively short (below average) periods of time.

- Far West was an area of high volatility in terms of recruitment and retention, which is likely to exacerbate access to justice problems for disadvantaged people. 
- There was no Legal Aid NSW office in the region (and, therefore, no possible retention or recruitment issues for this service).

- Noting there were only six private solicitors based in the Far West, there were no care and protection panel members and just one civil law panel member in this region.

\section{Murrumbidgee}

- Murrumbidgee had one resident solicitor for every 1000 residents.

- There were nine Legal Aid NSW and six ALS solicitor positions in this region (but no CLC office in this region).

- Two of the 15 public legal assistance solicitor positions were vacant (13 per cent compared to the state average of 7 per cent).

- All ALS and Legal Aid NSW positions had been filled for only relatively short (below average) periods of time. Four of the five ALS solicitors had been in the position for no more than six months. The Legal Aid NSW solicitors had been in the positions for an average of seven months (compared to the state average of 19 months).

- Based on population share, this region had fewer than expected private solicitor panel members across all areas of law.

\section{$3 \quad$ North Western}

- North Western had one resident solicitor for every 1000 residents.

- There were nine Legal Aid NSW, 12 ALS and three CLC solicitor positions in this region.

- Three of the 24 public legal assistance solicitor positions were vacant (12.5 per cent compared to the state average of 7 per cent).

- Both the vacant Legal Aid NSW positions had remained unfilled for 10 months (double the state average).

- The ALS and Legal Aid NSW positions had been filled for only relatively short periods of time. The average time ALS solicitors had been in the position was 12 months (compared to the ALS state 
average of 42 months). Six of the 11 filled ALS positions had been occupied for no more than six months. The Legal Aid NSW solicitors had been in the positions for an average of seven months (compared to the state average of 19 months).

- This region had no private solicitor civil law panel members and, based on population share, fewer than expected care and protection private solicitor panel members.

While Far West, Murrumbidgee and North Western regions stood apart, other regions - and notably not just RRR regions - had their own lawyer availability, recruitment and/or retention. ${ }^{13}$

\section{Regional Differences in Solicitor Characteristics}

Another variable to be considered in the discussion of recruitment and retention is the regional variation in the characteristics of solicitors (public and private) attracted to work in RRR areas. The two major sources of data for this information were the NSW Law Society data and the qualitative interviews. The Law Society data indicated that the average age of solicitors increased from the 'Major Cities' to Inner Regional and Outer Regional parts of the state, before decreasing slightly in the Remote/Very Remote areas. The years of experience as a solicitor showed a similar but more pronounced pattern in that years of experience dropped more steeply in the Remote/Very Remote areas (Figure 2).

Together these points show that solicitors based in the more remote areas of NSW were generally not only younger but the least experienced, whereas solicitors in Inner and Outer Regional areas of NSW were both older and more experienced than solicitors elsewhere in the state (including Sydney, which is where most new solicitors receive their initial training).

This finding is of interest given the high levels of disadvantage in Remote/Very Remote areas and the particular difficulties faced by lawyers in these regions. As noted from the interviews, these difficulties included challenging clients, high volume and stressful work, adverse work environments, being remote from supervision and support, and being distant from social and family networks. Given these difficulties, it would seem that solicitors in Remote and Very Remote areas would require more rather than less experience in order to sustain high quality legal services.

\footnotetext{
${ }^{13}$ See Forell, Cain and Gray, above n 8, in particular 'Region profiles' at 88-99.
} 
Figure 2: NSW solicitors - age and years of experience by remoteness area $(A R I A+)$

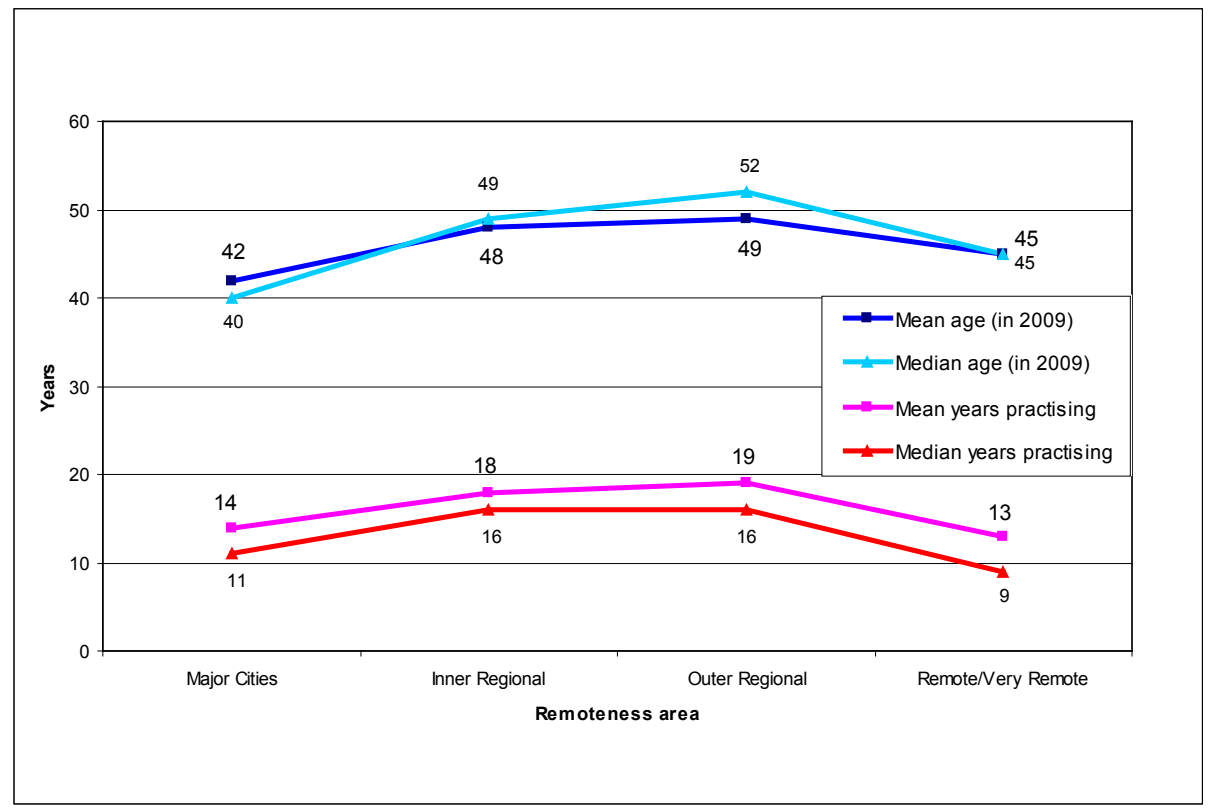

Source: Law Society of NSW database (30 June 2009). Derived from Table 12 in full report.

\section{E Regional Differences in Recruitment and Retention: What Made the Difference?}

RRR areas in NSW are not homogeneous in terms of their capacity to attract and retain public sector lawyers. There were some rural and regional areas which appeared more attractive to public and private sector lawyers than others, and these areas seemed better able to retain skilled and experienced solicitors for longer periods.

The interviews with lawyers working in or who had left the ALS, Legal Aid NSW, CLCs and private firms undertaking legal aid work in RRR NSW provided some insights into the factors which influenced their decision to move to, stay in or leave an area. Chief among these reasons were:

- $\quad$ personal reasons (such as family issues);

- the nature of the work and professional development opportunities offered; 
- the opportunity to save money;

- lifestyle, including social and community networks and distance from 'home'.

Particular attention was paid to how these factors may vary from area to area.

A key issue arising from the small number of in-depth interviews was just where lawyers considered 'home'. All except one of the 16 solicitors interviewed were born in Sydney, interstate or overseas. With all of the interviewed lawyers having attended city (NSW or interstate) universities, each had (at least some) social and family networks in areas other than the RRR areas in which they were working. A common reason given for leaving a rural area involved personal factors, such as a solicitor needing or wishing to return to family, or the solicitor's partner taking a job elsewhere. Notably, these reasons did not reflect any particular characteristic of the current work location, aside from the fact that the RRR location was distant from the place to which the solicitor returned.

The opportunity to get a legal job, or to obtain particular legal experience, appeared to be an important lure for some solicitors to rural public legal assistance positions, and this appeared to hold true regardless of where these work opportunities were located in RRR NSW. While this warrants further examination, it appeared that interviewees who took positions with Legal Aid NSW, CLCs or the ALS in order to get experience were less selective about the location in RRR NSW they went to, compared to people who moved to a rural location for lifestyle reasons. Similarly, people seeking the opportunity to work with disadvantaged Indigenous communities were prepared to go to remote and very remote locations. However, this group of lawyers also tended to have a finite timeframe in mind for their return to 'the city'. The social justice imperative was also a drawcard for many solicitors to work in the community legal sector and, in the case of private lawyers, to do legal aid work. However, this motivation is not necessarily unique to public legal assistance positions in RRR areas.

While the lawyers interviewed generally indicated that they did not go to work in rural community sector jobs 'for the money', the opportunity to save money was consistently raised as a factor relevant to decisions to take, stay in or leave a country job. Some solicitors were drawn to certain RRR areas by the lower cost of living and were prepared to consider their salary level in this context. Many left the job (often to go to a higher paying public legal sector job if it was available) for financial reasons. What was noted from the interviews was that, where the work stress was high, the costs of living high, 
and/or the lifestyle poor (ie, in very remote parts of NSW), the salary package became a far more prominent reason for staying in or leaving a RRR area.

One reason that ALS and CLC solicitors gave for leaving their country position was to take a job in Legal Aid NSW which, as a general rule, provided a higher salary level for equivalent positions. The salary data collected through the census of public legal assistance solicitor positions bore this out (Table 2).

The salary in Legal Aid NSW was roughly one-third higher than most similarly graded positions in CLCs and the ALS. The issue for rural areas is that Legal Aid NSW offices are located in cities or major regional centres and, therefore, are based no further out than Inner Regional areas of NSW. Should solicitors in remote areas wish to change jobs, including going to work for Legal Aid NSW, they are usually lost from the more remote communities.

Table 2: Mean and median annual salaries* for Legal Aid NSW, ALS and CLCs solicitors, 30 June 2009

\begin{tabular}{|l|r|r|}
\hline & \multicolumn{2}{|c|}{ Annual salary } \\
\hline Agency & Mean & Median \\
\hline Legal Aid NSW & $\$ 87548$ & $\$ 88955$ \\
\hline ALS (NSW/ACT) & $\$ 58883$ & $\$ 52000$ \\
\hline CLCs (NSW) & $\$ 59155$ & $\$ 55577$ \\
\hline
\end{tabular}

* Based on calculation of mid-point salary.

Source: LJF census of NSW public legal assistance solicitor positions (30 June 2009).

Derived from Table 21 in full report.

Consistent with earlier research, the availability of a professional and personal network in a region did appear to help sustain solicitors in rural areas. Solicitors working in the Richmond-Tweed region in part attributed their interest in staying in the area to the relatively strong legal fraternity in the region, as well as a shared interest in social justice issues. Other regions, including the Far West, were in the process of building these types of networks. By contrast, personal and professional isolation was given as a reason for leaving RRR areas that lacked such features.

While office infrastructure and support were not the main reason given by solicitors for leaving a RRR public legal assistance position, limited office assistance and support did appear to wear solicitors down, particularly in 
stressful and high volume work environments. Interviewees also highlighted the need for effective supervision of solicitors who had accepted positions in regional areas in order to get experience and the need for locum support for leave and training opportunities. This appeared to be a particularly critical issue in the more remote offices.

The remoteness of a legal office's location was a characteristic that, from both the qualitative and quantitative data, increased the degree of difficulty in filling solicitor positions and in retaining staff in these positions for any length of time. Remote offices were described as difficult, isolated and lonely places to work. Solicitors and managers interviewed for this study expressed the view that the long-term retention of solicitors may remain a challenge in remote areas, regardless of what strategies are introduced and what incentives are offered. This suggests that strategies aimed at better managing the reality of short-term retention may be more appropriate.

Finally, the research indicated that, as might be expected, there are idiosyncratic reasons for solicitors leaving a position or RRR location. For instance, personality clashes, difficulties between management and staff, and challenging external players in the justice system can affect solicitor retention in any public legal service, regardless of where the office is located.

\section{Strategies to Address Recruitment, Retention AND LAWYER AVAILABILITY ISSUES}

The results of this study suggest that any new strategies take the following points into account:

1. The realities of recruitment, retention and lawyer availability problems, namely:

- that some RRR areas are experiencing economic, social and population decline and resident services, including legal services and private solicitor numbers, are expected to continue to decline accordingly;

- that, in general, the more remote the area, the greater the level of disadvantage, the more difficult the legal working conditions and the greater the difficulty in attracting and retaining lawyers, especially experienced lawyers; 
- that some RRR areas are especially vulnerable to recruitment and retention problems and, without innovative solutions, will generally attract only relatively inexperienced solicitors and/or solicitors prepared to stay for a fixed and relatively short period of time; and

- that, given the challenging nature of legal work in the more remote parts of the state, a more senior solicitor may be needed, as a minimum, to staff these offices.

2. Different RRR areas have their own unique characteristics. Some RRR areas have recruitment and retention difficulties and some do not. The difficulties experienced vary from region to region and not all RRR areas are equally difficult to staff. Consequently, a single 'blanket' solution is unlikely to work. In fact, any 'RRR-wide' scheme that does not differentiate rewards to focus on the remote, problematic areas may simply make already attractive (and less problematic) parts of coastal and inner regional NSW even more attractive.

3. Solutions to address recruitment and retention issues in RRR areas need to be both location-specific and problem-orientated. That is, solutions need to be individually tailored to specific problems and their impact and effectiveness monitored and assessed.

4. The results of this study, including interviews with rural solicitors and managers, support frameworks, strategies and solutions that are responsive to the particular needs of identified 'hard to staff' areas. These might be, for instance:

- the differentiation of remuneration and conditions packages to provide greater benefits in those areas experiencing the most difficulties in attracting and retaining solicitors who have the right skills and experience;

- priority consideration being given for a move to a more favourable location and/or a more senior position after a remote area posting (where applicable to the organisation);

- the provision of appropriate office infrastructure and clerical and para-legal support. This includes the capacity to use up-to-date information technology to facilitate communication and support; 
- the building of professional networks in RRR areas, such as through the Cooperative Legal Service Delivery Program ${ }^{14}$ and interagency professional networks;

- the use of video conferencing to provide adequate supervision, mentoring and professional advice/support for staff in the more remote offices;

- a locum solicitor system which provides support for small rural offices which are understaffed or would otherwise be un-staffed during a solicitor's absence (for training, holidays, illness) and/or where there is higher staff turnover. This solution would be appropriate if the practice were contemplating investing in extra personnel.

5. The disparity in the salaries of similarly graded solicitor positions between the CLCs, the ALS and Legal Aid NSW almost certainly contributes to the movement of solicitors from the CLCs and the ALS to Legal Aid NSW and the private sector. This may also result in a movement of solicitors from more remote areas to inner regional areas and urban areas.

6. Recent graduates, including career change solicitors, are a major source of staff for many rural and remote offices, especially given the relatively low salaries offered in some organisations. These relatively inexperienced solicitors require appropriate professional supervision and mentoring, particularly in remote, isolated and challenging environments, yet difficulties attracting senior lawyers to these areas impede this.

7. Particularly in the absence of a capacity to offer higher salaries, it may be pragmatic to accept the reality of short-term retention in remote locations and to structure services to accommodate this, rather than expect or hope that solicitors will stay for longer periods. (A 'hub and spoke' system, whereby staff are based in a regional office but spend fixed periods at remote offices, is already being trialled in remote NSW by the ALS, and is worth monitoring into the future.)

${ }^{14}$ The Cooperative Legal Service Delivery Program (CLSD) brings together government, community and private sector agencies in a regional and cooperative approach to delivering legal services. For more information on the CLSD see <http://www.legalaid.nsw.gov.au/asp/ index.asp?pgid $=769 \& \mathrm{cid}=1034 \& \mathrm{id}=694>$. 
8. It may never be realistic to provide resident solicitors/legal services in certain particularly remote areas. These areas may simply not have the population to sustain a viable legal practice, whether that is a private practice or a public legal assistance service. Alternative models of legal service delivery such as outreach or 'fly in fly out' models may be more appropriate. The determination of just which strategies are best suited to each particular area is beyond the scope of this research or its findings, but represents an important topic for future research.

Finally, this study has identified benefits and flexibility which come with being a statewide service. Both Legal Aid NSW and the ALS NSW/ACT have some capacity to move staff between their city and different regional and rural offices. Staff vacancies may be covered by other solicitors employed by these organisations, subject to flow-on staffing constraints. In contrast, CLCs, which operate largely independently of one another, and with varying sources of funding, do not have this flexibility. Strategies to provide CLCs with more capacity to cover shortages in RRR areas may warrant further consideration.

\section{Conclusion}

The problems associated with the recruitment and retention of solicitors in regional, rural and remote NSW are more nuanced than the broad 'city' versus 'country' divide commonly advocated. The census of all private solicitors and public legal assistance solicitor positions in NSW undertaken in this study indicated that problems in recruiting and retaining solicitors for publicly funded legal assistance work in RRR NSW were typically location-specific and often position-specific. The implication of this finding is that 'blanket' solutions that treat regional, rural and remote areas as a homogeneous entity may be less effective.

This study has indicated that the more remote the area, the higher the likelihood of recruitment and retention problems. Solicitors working in remote and very remote areas of NSW deal not only with extremely testing physical environments but also with the fact that these areas have the smallest ratio of solicitors to residents, a highly disadvantaged client base and a general lack of professional support and office infrastructure. The poor salary packages for solicitors employed by the public legal assistance services based in these areas (ie, the Aboriginal Legal Service and Community Legal Centres, but not Legal Aid) further increase the likelihood of these areas attracting only relatively inexperienced solicitors and keeping them for relatively short periods of time. 
The continuing economic and social decline in many parts of RRR Australia is considered to be inevitable. Declining populations in many RRR areas are likely to cause a further loss of private solicitors and, therefore, a loss of solicitors available to do legal aid work. In these circumstances public legal assistance services in RRR areas would need to be retained and in fact bolstered, assuming that this is possible. Alternatively, private solicitors in declining areas may become more dependent on legal aid work to sustain their rural practices. In any case, alternative models of legal service delivery may be increasingly necessary in these areas. 